Огляди літератури, оригінальні дослідження, погляд на проблему

удК 616.5-001/-002-091.8-085.275.4-022.532]-092.9

DOI 10.11603/1811-2471.2017.v1.i3.8177

\title{
СТРУКТУРНІ ЗМІНИ ШКІРИ ПРИ КОНТАКТНОМУ НІКЕЛЕВОМУ ДЕРМАТИТІ ЗА УМОВ ПРИГНІЧЕННЯ INOS
}

\author{
๑І. І. Худан-Цільо, М. М. Корда
}

ДВНЗ “Тернопільський державний медичний університет імені І. Я. Горбачевського МОз України"

Робота виконана в рамках НдР 0112 Ч000542 «Біохімічні механізми токсичності наночастинок різної природи та інших антропогенних і біогенних токсикантів і біологічних систем» та 0116 бо03353 «Біохімічні механізми порушень метаболізму за умов надходження до організму токсикантів різного ґенезу».

РЕзюМЕ. Пошук ефективнихта безпечних методів лікування алергійних дерматозів залишається актуальною проблемою сучасної дерматології. В останні роки значна увага приділяється вивченню ролі оксиду азоту в регуляції функціонування різних систем організму, в тому числі при алергійних дерматитах, та можливостей застосування нанотехнологій для лікування шкірних хвороб.

Метою дослідження стало вивчення особливостей реорганізації структури шкіри при експериментальному контактному нікелевому дерматиті та його корекції препаратами високоселективного інгібітора індуцибельної NO-синтази N-(3-(Амінометил)бензил)ацетамідину (1400W) у вільній та наноінкапсульованій формах.

Матеріал і методи. Експеримент проведено на 35 статевозрілих білих щурах, яких було поділено на 4 групи: 1 - інтактні тварини; 2 - щури з модельованим контактним нікелевим дерматитом (КД); 3 - щури з КД, яким для корекції застосовували 1400W (КД + 1400W); 4 - щури з КД, яким наносили інкапсульовану 1400W (КД + нано-1400W). Полімерні хітозанові наночастинки з інкапсульованим 1400W готували за методикою Hussain Z. et al. (2013). Препарати для корекції наносили на уражені ділянки шкіри два рази на добу протягом 7 днів. Тварин виводили 3 експерименту на 20 добу дотримуючись усіх правил біоетики. Для оцінки структурних змін проводили гістологічне дослідження шкіри за загальноприйнятими методиками.

Результати. На мікроскопічному рівні встановлено, що у центральних ділянках шкіри при нікелевому дерматиті відбувається глибока деструкція епідермісу та дерми з вогнищевими виразковими пошкодженнями. Застосування вільної форми 1400W не приводило до покращення структур шкіри. При аплікації наноформи спостерігалася деяка активація процесів регенерації: мікроскопічно відмічався лише вузький новоутворений пласт клітин без пошарового диференціювання.

Висновки. Застосування наноформи препарату $1400 \mathrm{~W}$ забезпечує більш активну репарацію пошкоджених структур шкіри та стимулює крайову епітелізацію. Для подальшого вивчення $є$ перспективним дослідження можливостей комбінування наноінкапсульованого препарату $1400 \mathrm{~W}$ з іншими патогенетичними чинниками для лікування та корекції контактного алергійного дерматиту.

КлючовІ СлОВА: структурні зміни; шкіра; дерматит; нікель; високоселективний інгібітор iNOS 1400W; наноформа.

Вступ. Пошук ефективних та безпечних методів лікування алергійних дерматозів залишається актуальною проблемою сучасної дерматології $[1,2]$. В останні роки значна увага приділяється вивченню ролі оксиду азоту (NO) в регуляції різних систем організму та його участі у патогенезі більшості хронічних захворювань, в тому числі при алергійних дерматитах [3-5].

NO синтезується в результаті реакцій метаболізму L-аргініну, які каталізуються NO-синтазою (NOS) [3]. Розрізняють три її ізоформи: нейрональну (nNOS), індуцибельну (iNOS) та ендотеліальну (eNOS) [3]. Як внутрішньоклітинний і міжклітинний месенджер NO бере участь у регуляції низки метаболічних реакцій, відіграє важливу роль у синаптичній передачі нервового імпульсу, регуляції кровопостачання шлункового тракту, секреції інсуліну, розвитку діабету тощо $[6,7]$. Активність NO-синтази зафіксовано у ендотелії, головному мозку, клітинах крові, у нирках, епітелії легеневого дерева, міокарді $[3,4]$. Індукований синтез NO відіграє важливу роль у функціонуванні гепатоцитів і захищає печінку від септичної та ішемічної реперфузії. Оксид азоту виконує як прозапальну, так і протизапальну роль. Присутність iNOS у активованих макрофагах, лімфоцитах та нейтрофілах вказує на те, що NO відіграє важливу роль у запаленні та розвитку імунної відповіді. Відомо, що при алергійних запальних процесах шкіри фіксується підвищення продукції оксиду азоту, що призводить до наростання ексудації та розвитку набряку тканин. Розвиток нітрооксидативного стресу стимулює активацію еозинофільного запалення та прогресування захворювання [8]. До сьогодні немає чітких даних щодо структурних змін шкіри при контактному алергійному дерматиті (КД) за умов модуляції нітрооксидативного стресу.

Ще однією складністю лікування КД $\epsilon$ доставка лікувальних компонентів до глибоких шарів епідермісу та дерми через stratum corneum. Для полегшення проходження цього природного бар'єру 
Огляди літератури, оригінальні дослідження, погляд на проблему

сьогодні часто застосовують нанотехнології (інкапсульовані наноформи лікарських засобів) [9].

Метою нашого дослідження стало встановлення особливостей реорганізації структури шкіри при експериментальному контактному нікелевому дерматиті за умов застосування для корекції високоселективного інгібітора індуцибельної NO синтази N-(3-(Амінометил)бензил)ацетамідину (1400W) у вільній та нанокапсульованій формах.

Матеріал і методи дослідження. Досліди проведено на 35 статевозрілих білих щурах-самцях масою 180-220 г, яких методом сліпої вибірки було рандомізовано на чотири групи: 1 - інтактні тварини (5 особин); 2 - тварини з експериментальним контактним нікелевим дерматитом (КД) (10 особин); 3 - щури з КД, яким для корекції застосовували 1400W (КД + 1400W); 4 - щури з КД, яким наносили інкапсульовану $1400 \mathrm{~W}$ (КД + нано1400W). При проведенні досліджень дотримувалися міжнародних правил та принципів «Європейської конвенції про захист хребетних тварин, які використовуються для експериментів та з іншою науковою метою» (Страсбург, 1986) і Закону України «Про захист тварин від жорстокого поводження» (№ 1759-VI від 15.12.2009) та Директиви Європейського Союзу 2010/10/63 EU щодо експериментів на тваринах.

Контактний нікелевий дерматит моделювали шляхом щоденного нанесення впродовж 12 днів на ретельно вистрижену ділянку шкіри (площею $3 \times 3$ см) щурів 4 г водного ланоліну, що містив 5 \% $\mathrm{NiSO} 4$.

Для досліджень використовували високоселективний інгібітор індуцибельної NO-синтази $\mathrm{N}$-(3-(Амінометил)бензил)ацетамідин (1400W) (Sigma, Aldrich, USA). Наночастинки з інкапсульованим $1400 \mathrm{~W}$ готували за методикою Hussain Z. et al. [10]. Полімерні хітозанові наночастинки готували шляхом іонного «зшивання» хітозану з триполіфосфатом натрію (ТРP). Розчин хітозану (0,2 \%) готували на 1 \% розчині оцтової кислоти (pH=5) i інкубували, перемішуючи з 1400W (1 мг/мл) протягом 30 хв при кімнатній температурі. До 25 мл інкубаційної суміші по краплях додавали 10 мл 0,1 \% водного розчину ТРP. Суміш постійно перемішували за допомогою магнітної мішалки (700 о6/хв). Отримані наночастинки відцентрифуговували (28000 об/хв) протягом 30 хв. Розмір наночастинок визначали за допомогою морфометричної програми ВідеоТест - 5.0, КААРА ImageBase, за даними електронної мікроскопії їх розмір коливався від 40 до 100 нм.

$1400 W$ та його нанокапсульовану форму у вигляді суміші з водним ланоліном після формування контактного нікелевого дерматиту наносили протягом 7 днів на уражену ділянку шкіри 2 рази на добу. Декапітацію тварин проводили під тіопенталовим наркозом на 20 день експерименту. Забір матеріалу для гістологічних досліджень проводили згідно із загальноприйнятими методиками. Шматочки шкіри фіксували в 10 \% розчині нейтрального формаліну, зневоднювали та заливали в парафінові блоки. Отримані на санному мікротомі зрізи забарвлювали гематоксиліном-еозином. Гістологічні препарати вивчали за допомогою світлового мікроскопа SEOSCAN та фотодокументували за допомогою відеокамери Vision CCD Cameга.

Результати й обговорення. Проведені дослідження показали розвиток максимального ураження при контактному нікелевому дерматиті у центральній ділянці контакту з подразником (рис. 1). У межах потовщеного епідермісу відмічалися значні округло-овальні порожнини, заповнені гомогенізованими склеєними еритроцитами та пошкодженими лейкоцитами. Під пошкодженим епідермісом у сосочковому шарі дерми були розширені просвіти судин мікроциркуляторного русла, значні ділянки крововиливів. Набряк пухкої сполучної тканини супроводжувався лізисом волокон та деструкцією фібробластів.

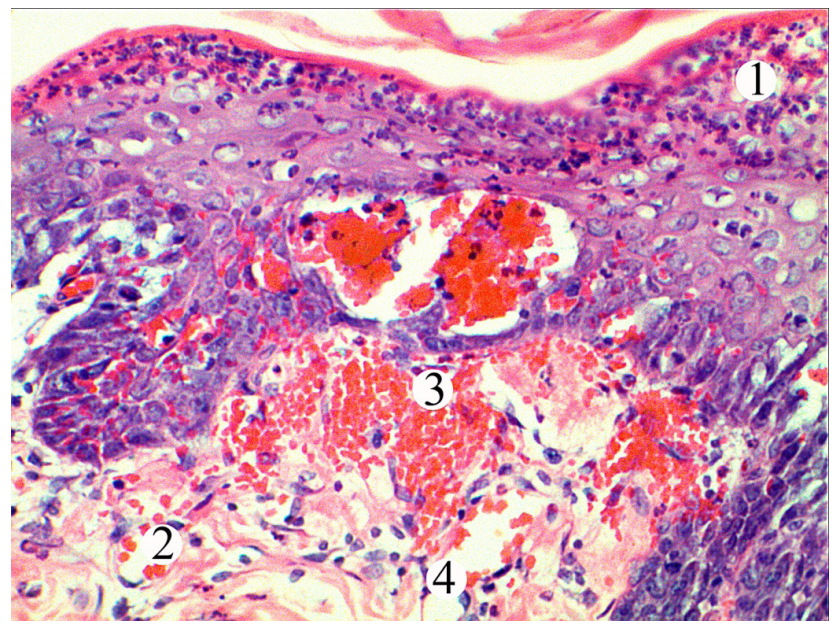

Рис. 1. Мікроскопічні зміни епідермісу і дерми шкіри тварини при експериментальному дерматиті. Центральна ділянка ураженого епідермісу і дерми. Деструкція та лейкоцитарна інфільтрація епідермісу (1), розширені просвіти гемокапілярів (2), крововиливи (3), набряк сполучної тканини дерми (4). Забарвлення гематоксиліном та еозином. $\times 200$.

На поверхні виразок формувалася кірка з клітинного детриту, фібрину, яка була тісно спаяна з підлеглою пошкодженою тканиною і відмежована грануляціями. Суттєво пошкоджувалися придатки шкіри. Більшість клітин всіх шарів були пікнотично змінені, пошкоджувалися міжклітинні контакти та простори. Пошкодження дерми, її придатків та судин у периферійних ділянках були меншими, ніж у центральних. 
Проведені мікроскопічні дослідження шкіри тварин при експериментальному дерматиті за умов застосування вільної форми препарату $1400 \mathrm{~W}$ показали, що його позитивний вплив був незначним. У місцях ураженої дерматитом шкіри було зафіксовано деструкцію клітин епідермісу, структурних компонентів сосочкового і сітчастого шарів дерми (рис. 2).

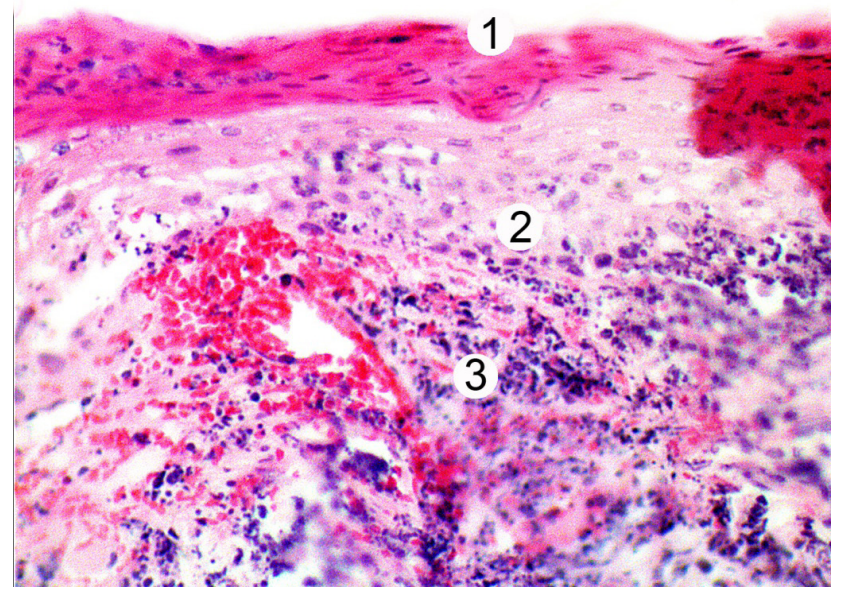

Рис. 2. Гістологічні зміни епідермісу та компонентів дерми шкіри тварини при експериментальному дерматиті за умов застосування препарату $1400 \mathrm{~W}$. Пошкоджений епідерміс (1) та дерма (2), лейкоцитарна інфільтрація міжклітинної речовини (3). Забарвлення гематоксиліном та еозином. 200.

Епідермоцити по краях пошкодженої шкіри були збережені, проте крайова епітелізація практично відсутня. Дерма все ще була набряклою, судини мікроциркуляторного русла розширені та кровонаповнені.

Гістологічні дослідження шкіри тварин при експериментальному дерматиті за умов застосування наноформи препарату $1400 \mathrm{~W}$ показали, що покращення ії структурних компонентів було більш вираженим у порівнянні з застосуванням його вільної форми. Спостерігалися морфологічні ознаки активації регенераторних процесів.

У центральних ділянках встановлено закриття дефектів шкіри щільним шаром - кіркою, яка утворена на місці повністю зруйнованого епідермісу і сосочкового шару дерми. Мікроскопічно під нею відмічався вузький новоутворений пласт клітин без пошарового диференціювання (рис. 3).

В оновленні епідермісу брали участь епітеліоцити, які збереглися у крайовій ділянці, а також за рахунок клітин придатків шкіри. Сосочковий шар дерми включав камбіальні та зрілі фібробласти, які беруть участь у оновленні волокон та аморфної речовини сполучної тканини. Кровоносні капіляри дерми мають широкі та кровонаповнені просвіти, все ще були наявні периваскулярний набряк та лейкоцитарна інфільтрація.

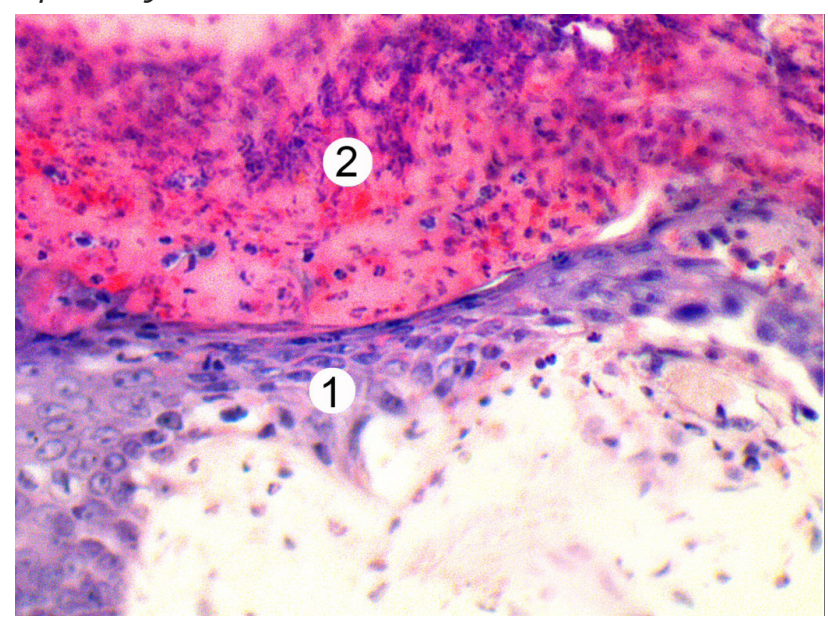

Рис. 3. Мікроскопічна організація епідермісу та структур дерми центральної ділянки шкіри тварини при експериментальному дерматиті за умов застосування наноформи та препарату 1400W. Епітеліальний пласт (1), поверхнева кірка (2), дерма (3). Забарвлення гематоксиліном та еозином. $x 300$.

Отже, застосування інгібітора iNOS 1400W не викликає значного покращення структурних компонентів шкіри при експериментальному контактному нікелевому дерматиті, що свідчить про значну питому вагу в розвитку патологічного процесу інших механізмів та чинників. Однак, застосування високоселективного інгібітора індуцибельної NO синтази N-(3-(Амінометил)бензил)ацетамідину $1400 \mathrm{~W}$, інкапсульованого у хітозанові наночастинки, забезпечує більш активну репарацію пошкоджених структур шкіри та стимулює крайову епітелізацію.

Висновки. 1. Застосування протягом 12 днів 5 \% нікелю сульфату призводить до формування виражених ознак контактного нікелевого дерматиту та пошкодження структур шкіри у досліджуваних тварин. Зміни найвираженіші у центральних ділянках контакту та менше - на периферії.

2. Аплікація вільної форми високоселективного інгібітора індуцибельної NO синтази N-(3(Амінометил)бензил)ацетамідину $1400 \mathrm{~W}$ на уражені ділянки шкіри мала незначний позитивний вплив на її структурні компоненти. Все ще були ділянки глибокої деструкції епідермального пласта, сосочкового і сітчастого шарів дерми та її придатків. Крайова епітелізація практично відсутня.

3. Застосування наноформи $1400 \mathrm{~W}$ забезпечує більш активну репарацію пошкоджених структур шкіри (формується вузький новоутворений пласт клітин без пошарового диференціювання) та стимулює крайову епітелізацію.

4. Застосування наноінкапсульованої форми препарату $1400 \mathrm{~W}$ можна розглядати як перспективний метод для подальшого вивчення можливостей його комбінування при терапії дерматитів. 
Огляди літератури, оригінальні дослідження, погляд на проблему

\section{ЛІТЕРАТУРА}

1. Allergic contact dermatitis: epidemiology, molecular mechanisms, in vitro methods and regulatory aspects / M. Peiser, T. Tralau, J. Heidler [et al.] // Cell. Mol. Life Sci. 2012. - N 69 (5). - P. 763-781.

2. Allergic Contact Dermatitis / L. Kostner, F. Anzengruber, C. Guillod [et al.] // Immunol. Allergy Clin. North Am. - 2017. - N 37(1). - P. 141-152.

3. Сибірна Н. О. Молекулярні механізми депонування оксиду азоту в еритроцитах / Н. О. Сибірна, M. Я. Люта, Н. І. Климишин // Біологічні Студії/Studia Biol. - 2010. - № 4 (1). - C. 143-160.

4. Ross R. The role of NO in contact hypersensitivity / R. Ross, A. B. Reske-Kunz //Int. Immunopharmacol. -2001.№ 1 (8). - P. 1469-1478.

5. Li H. Vascular oxidative stress, nitric oxide and atherosclerosis / H. Li, S. Horke, U. Förstermann // Atherosclerosis. - 2014. - N 237 (1). - P. 208-219.

6. Hydrogen sulfide and nitric oxide interactions in in- flammation / M. L. Lo Faro, B. Fox, J. L. Whatmore [et al.] // Nitric Oxide. - 2014. - N 41. - P. 38-47.

7. Sharma J. N. Role of nitric oxide in inflammatory diseases / J. N. Sharma, A. Al-Omran, S. S. Parvathy // Inflammopharmacology. - 2007. - N 15 (6). - P. 252-259.

8. Смирнова И. Ю. Роль оксида азота в развитии заболеваний кожи / И. Ю. Смирнова, Л. М. Огородова, И. А. Деев // Вопросы современной педиатрии. - 2009. Т. 8, № 4. - C. 90-94.

9. Nanoparticles and nanofibers for topical drug delivery / R. Goyal, L. K. Macri, H. M. Kaplan [et al.] // Journal of Controlled Release : Official Journal of the Controlled Release Society. - 2016. - N 240. - P. 77-92.

10. Self-assembled polymeric nanoparticles for percutaneous co-delivery of hydrocortisone/hydroxytyrosol: an ex vivo and in vivo study using an NC/Nga mouse model / Z. Hussain, H. Katas, M. C. Mohd Amin [et al.] // Int. J. Pharm. - 2013. - Vol. 444, issue 1-2. - P. 109-119.

\title{
REFERENCES
}

1. Peiser, M., Tralau, T., Heidler, J., Api, A. M., Arts, J. H. E., Basketter, D. A., ... Luch, A. (2012). Allergic contact dermatitis: epidemiology, molecular mechanisms, in vitro methods and regulatory aspects: Current knowledge assembled at an international workshop at BFR, Germany. Cellular and Molecular Life Sciences, 69 (5), 763-781. http://doi.org/ 10.1007/s00018-011-0846-8

2. Kostner, L., Anzengruber, F., Guillod, C., Recher, M., Schmid-Grendelmeier, P., \& Navarini, A. A. (2017). Allergic contact dermatitis. Immunology and Allergy Clinics, 37(1), 141-152.

3. Sybirna, N.O., Lyuta, M.Ya., \& Klymyshyn, N.I. (2010). Molekuliarni mekhanizmy deponuvannia oksydu azotu $v$ erytrotsytakh [Molecular mechanisms of deposit of nitric oxide in erythrocytes]. Biolohichni studii - Biological Studios, 4 (1), 143-160 [in Ukrainian].

4. Ross, R., \& Reske-Kunz, A. B. (2001). The role of NO in contact hypersensitivity. International Immunopharmacology, 1 (8), 1469-1478.

5. Li, H., Horke, S., \& Förstermann, U. (2014). Vascular oxidative stress, nitric oxide and atherosclerosis. Atherosclerosis, 237 (1), 208-219.

6. Faro, M. L. L., Fox, B., Whatmore, J. L., Winyard, P. G. \& Whiteman, M. (2014). Hydrogen sulfide and nitric oxide interactions in inflammation. Nitric Oxide, 41, 38-47.

7. Sharma, J. N., Al-Omran, A., \& Parvathy, S. S. (2007). Role of nitric oxide in inflammatory diseases. Inflammopharmacology, 15 (6), 252-259.

8. Smirnova, I.Yu., Ogorodova, L.M., \& Deyev, I.A. (2009). Rol oksida azota v razvitii zabolevaniy kozhi [The role of nitric oxide in the development of skin diseases]. Voprosy sovremennoy pediatrii, 8 (4) [in Russian].

9. Goyal, R., Macri, L. K., Kaplan, H. M., \& Kohn, J. (2016). Nanoparticles and nanofibers for topical drug delivery. Journal of Controlled Release: Official Journal of the Controlled Release Society, 240, 77-92.

10. Hussain, Z., Katas, H., Amin, M. C. I. M., Kumolosasi, E., Buang, F., \& Sahudin, S. (2013). Self-assembled polymeric nanoparticles for percutaneous co-delivery of hydrocortisone/hydroxytyrosol: an ex vivo and in vivo study using an $\mathrm{NC} / \mathrm{Nga}$ mouse model. International Journal of Pharmaceutics, 444 (1), 109-119.

\section{СТРУКТУРНЫЕ ИЗМЕНЕНИЯ КОЖИ ПРИ КОНТАКТНОМ НИКЕЛЕВОМ ДЕРМАТИТЕ В УСЛОВИЯХ УГНЕТЕНИЯ INOS}

\author{
○И. И. Худан-Цильо, М. М. Корда
}

\author{
гвуз «Тернопольский государственный медицинский университет имени И. Я. Горбачевского \\ МЗ Украины»
}

PЕЗЮМЕ. Поиск эффективных и безопасных методов лечения аллергических дерматозов остается актуальной проблемой современной дерматологии. В последние годы значительное внимание уделяется изучению роли оксида азота в регуляции функционирования различных систем организма, в том числе при аллергических дерматитах, и возможностей применения нанотехнологий для лечения кожных болезней. 
Огляди літератури, оригінальні дослідження, погляд на проблему

Целью исследования стало изучение особенностей реорганизации структур кожи при экспериментальном контактном никелевом дерматите (КД) и его коррекции препаратами высокоселективного ингибитора индуцибельной NO-синтазы N-(3-(Аминометил)бензил)ацетамидина (1400W) в свободной и наноинкапсулированной формах.

Материал и методы. Эксперимент проведен на 35 половозрелых белых крысах, которые были поделены на 4 группы: 1 - интактные животные; 2 - крысы с моделируемым контактным никелевым дерматитом (КД); 3 - крысы с КД, которым для коррекции применяли 1400W (КД+1400W); 4 - крысы с КД, которым наносили инкапсулированную 1400W (КД+нано-1400W). Полимерные хитозановые наночастицы с инкапсулированным 1400W готовили по методике Hussain Z. et al. (2013). Препараты для коррекции наносили на пораженные участки кожи два раза в сутки в течение 7 дней. Животных выводили из эксперимента на 20 сутки соблюдая все правила биоэтики. Для оценки структурных изменений проводили гистологическое исследование кожи по общепринятым методикам.

Результаты. На микроскопическом уровне установлено, что в центральных участках кожи при никелевом дерматите происходит глубокая деструкция эпидермиса и дермы с очаговыми язвенными повреждениями. Применение свободной формы 1400W не приводило к улучшению структуры кожи. При аппликации наноформы наблюдалась некоторая активация процессов регенерации: микроскопически отмечался лишь узкий новообразованный пласт клеток без послойного дифференцирования.

Выводы. Применение наноформы препарата 1400W обеспечивает более активную репарацию поврежденных структур кожи и стимулирует краевую эпителизацию. Для дальнейшего изучения перспективным является исследование возможностей комбинирования наноинкапсулированного препарата $1400 \mathrm{~W}$ с другими патогенетическими факторами для лечения и коррекции контактного аллергического дерматита.

КЛЮЧЕВЫЕ СЛОВА: структурные изменения; кожа; дерматит; никель; высокоселективный ингибитор iNOS 1400W; наноформа.

\section{SKIN STRUCTURE CHANGES IN CONTACT NICKEL DERMATITIS AT INHIBITION OF INOS}

\section{Horbachevsky Ternopil State Medical University}

SUMMARY. The search of safe and effective methods of allergic dermatosis treatment is an actual problem of modern dermatology. Last decades the role of nitric oxide in body functions is under strict attention and study, in allergic dermatitis as well. Use of nanotechnologies has been increasingly raised to treat skin diseases.

The Aim of the investigation was to study the structural reorganization of skin in experimental contact nickel dermatitis and its correction with drugs of potent and selective inhibitor of inducible nitric oxide synthase (iNOS) N-([3(Aminomethyl)phenyl]methyl)ethanimidamide dihydrochloride (1400W) in free and nano-capsulated forms.

Materials and Methods. Experiment was carried out on 35 white inbred rats, which were divided into 4 groups. Group 1 - intact rats; 2 - rats with contact nickel dermatitis (CD); 3 - rats which got free form of 1400W (CD + 1400W); 4 - group which got nano-capsulated form of 1400W (CD + nano-1400W). Polymeric chitosan nanoparticles with encapsulated 1400W were prepared by method of Hussain Z. et al. (2013). 1400W preparations were applicated 2 times per day during 7 days. The rats were euthanized at the 20th day of the experiment in accordance to all bioethical principles. Histological examination of skin stripes was performed by routine methods.

Results. Histological examinations of the rat skin with CD showed signs of the most prominent destructive changes at the center of lesion. The epidermis destruction and areas of necrosis were observed. 1400W in free form did not produced any significant changes of skin structure. Application of nano-1400W promoted more active regeneration. Thin layer of epitheliocytes was produced without any differentiation.

Conclusions. Application of nano-encapsulated form of $1400 \mathrm{~W}$ was more efficient for improving of the skin structure reorganization at contact nickel dermatitis, compared to use of its free form. Reparation of skin was a little bit more active without differentiation of epithelium layers and decreasing of inflammation signs. Further study of combination of nano-1400W with other medications could be prospective.

KEY WORDS: structural changes; skin; dermatitis; nickel; high selective inhibitor iNOS 1400W; nanoform. 